\title{
INTERFERENSI SINTAKSIS BAHASA IBU TERHADAP KETERAMPILAN BERBICARA BAHASA ARAB \\ (Studi Kasus Mahasiswa Pendidikan Bahasa Arab STAI Syaichona Moh. Cholil Bangkalan)
}

\author{
Oleh: \\ Siti Maisaroh ${ }^{1}$ \\ Email: rislamd@googlemail.com
}

\begin{abstract}
Arabic is the second language that has to be learned in formal education institution and also becomes compulsory subject for students of Arabic department. Each language has different elements that make the students are difficult to master foreign language (Arabic). Moreover, language mastery must have four language skills where composition is one of skills in language. This article explains the result of the research concerns with the Indonesian language syntactical interference on Arabic speaking. Based on the result of the research, the ability of speaking or Arabic conversation still influenced by Indonesian language, even thought many students are able to speak with the appropriate grammar (nahwu and shorof) especially for the students of Arabic Department of Syaichona Moh. Cholil State Institute of Islamic Studies Bangkalan.
\end{abstract}

Key words: interferensi sintaksis, Bahasa Indonesia-Bahasa Arab

\section{Pendahuluan}

Sudah jamak diketahui, di berbagai belahan dunia saat ini, terlebih masyarakat Indonesia, nyaris tidak akan ditemui satu individupun yang monolingual, yaitu individu yang hanya menguasai satu bahasa saja, kecuali hanya beberapa kelompok kecil saja yang tinggal di daerah pedalaman yang hanya mengetahui satu jenis bahasa. Sebagai contoh Madura, seiring dengan perkembangan zaman, Madura yang secara geografis merupakan pulau kecil namun sekarang masyarakatnya sudah

${ }^{1}$ Dosen Prodi Pendidikan Bahasa Arab STAI Syaichona Moh. Cholil Bangkalan 
banyak berpacu dalam panggung keilmuan dan budaya modernitas, sehingga tuntutan penguasaan bilingual (mengetahui dua bahasa) maupun multilingual (mengetahui dua bahasa atau lebih) tak dapat terelakkan lagi.

Menilik perkembangan zaman yang di dalamnya ada sebuah budaya masyarakat, tentunya akan mengalami perubahan dan perkembangan. Terlebih karena masyarakat Madura saat ini sudah banyak menggunakan multilingual dalam kehidupan sehari-hari. Gesekan dan benturan-benturan bahasa di dalam pemakaiannya, baik secara lisan maupun tulisan, menjadi hal yang tidak dapat dihindari. Hal itu terjadi karena kontak bahasa dapat menyebabkan suatu bahasa terpengaruh oleh bahasa yang lain dan proses saling mempengaruhi antara bahasa yang satu dengan bahasa yang lain tidak dapat dihindarkan. Karena itu, sebuah niscaya jika bahasa pun turut serta mengalami perkembangan dan perubahan bahkan benturan dan kekacauan (baca: interferensi bahasa). Adapun beberapa faktor yang menyebabkannya ialah: faktor sosial, ekonomi, politik, dan budaya baik di kalangan internal Madura sendiri maupun dengan suku luar atau hubungan eksternal.

Menurut Weinrich ${ }^{2}$ dalam Chaer, kontak bahasa merupakan peristiwa pemakaian dua bahasa oleh penutur yang sama secara bergantian. Dari kontak bahasa itu terjadi transfer atau pemindahan unsur bahasa yang satu ke dalam bahasa yang lain yang mencakup semua tataran. Sebagai konsekuensinya, proses pinjam-meminjam dan saling mempengaruhi terhadap unsur bahasa yang lain tidak dapat dihindari. Apabila dua bahasa atau lebih digunakan secara bergantian oleh penutur yang sama, dapat dikatakan bahwa bahasa tesebut dalam keadaan saling kontak. Dalam setiap kontak bahasa terjadi proses saling mempengaruhi antara bahasa satu dengan bahasa yang lain. Sebagai akibatnya, interferensi (kekacauan bahasa) akan muncul, baik secara lisan maupun tulisan. Adapun interferensi masih menurut Weinreich (1953) adalah perubahan sistem suatu bahasa sehubungan dengan adanya persentuhan bahasa

\footnotetext{
${ }^{2}$ Abdul Chaer dan Leonie Agustina. Sosiolinguistik. (Jakarta: PT. Rineka Cipta,
} 1995), 159 
tersebut dengan unsur-unsur bahasa lain yang dilakukan oleh penutur bilingual. ${ }^{3}$

Fenomena masalah kebahasaan berupa kontak, benturan, dan gesekan antara dua bahasa atau lebih seperti di atas juga terjadi dalam pembelajaran bahasa yang bilingual dan multilingual. Hal ini juga terjadi dalam komunikasi mahasiswa Pendidikan Bahasa Arab (PBA) Sekolah Tinggi Agama Islam Syaichona Moh.Cholil (STAIS) Bangkalan. Mahasiswa yang berlatarbelakang budaya dan bahasa Madura tulen ini secara intensif dituntut untuk bergelut dengan bahasa asing (Bahasa Arab) karena tuntutan akademik yang dipilih. Maka apa yang disebut sebagai interferensi (gangguan atau kekacauan) bahasa dalam berkomunikasi lisan dan tulisan tentu tidak bisa dihindari. Sebagai contoh, dalam interferensi sintaksis adalah, kalimat, "hey.anta turĩd ilā ayna?" Untuk mengatakan maksud "kamu hendak pergi kemana wahai saudaraku". Jelas sekali, susunan sintaksis dalam kalimat tersebut terdapat campuran gaya Bahasa Madura atau Indonesia dalam Bahasa Arab. Padahal jika kita melihat susunan sintaksis yang benar dalam Bahasa Arab adalah seharusnya tersusun kalimat sebagai berikut, "Ilā ayna anta dzāhib yā akhĩ". Kekacauan sintaksis dalam komunikasi Bahasa Arab sehari-hari mahasiswa PBA STAIS Bangkalan adalah tidak sekali dua kali, bahkan menjadi kebiasaan yang tidak terkontrol.

Mahasiswa yang memilih jurusan Pedidikan Bahasa Arab tentunya menguasai Bahasa Arab sebagai bahasa keduanya, tapi dengan tingkat kemampuan yang berbeda-beda. Ada yang bahasa pertama (Bahasa Ibu) yaitu Bahasa Madura dengan bahasa kedua-dalam hal ini Bahasa Arabsama mahirnya, ada pula yang bahasa kedua kurang mahir, sehingga penggunan bahasa pertama lebih dominan dibanding bahasa kedua. Namun fenomena pembelajaran bahasa kedua (bahasa asing) -dalam hal ini Bahasa Arab- di STAIS Bangkalan terbilang kacau dan bermasalah, karena terjadinya kerancauan berbahasa asing.

Di sisi lain, STAIS Bangkalan merupakan salah satu Perguruan Tinggi Agama Islam Swasta yang di dalamnya terdapat program Markaz

${ }^{3}$ Abdul Chaer dan Leonie Agustina. Sosiolinguistik Perkenalan Awal. (Jakarta: Rineka Cipta, cet II, 2004), 120 
Lughah (Pusat Peningkatan Bahasa) ini mewajibkan mahasiswa menggunakan Bahasa Arab sebagai bahasa yang digunakan sehari-hari dalam berkomunikasi. Namun terdapat berbagai kendala dalam pelaksanaannya, seperti keadaan sekitar yang berinteraksi dengan Bahasa Indonesia ataupun Bahasa Madura. Di sisi lain para mahasiswa berusaha untuk mematuhi peraturan dan menjauhkan diri dari hukuman yang diterapkan oleh bagian bahasa, sehingga Bahasa Arab yang digunakan tidak memperhatikan kaidah yang berlaku. Proses mempelajari Bahasa Arab bagi penutur Indonesia adalah proses menguasai sistem berbahasa yang baru dan berbeda dengan apa yang terbiasa mereka pakai, baik dari aspek bunyi, bangunan kata, struktur kalimat, maupun sistem pemaknaan. Ketika proses tersebut berlangsung, secara alamiah akan terjadi interferensi linguistik Bahasa Madura terhadap Bahasa Arab, yaitu sebuah kecenderungan penutur Madura untuk menggunakan Bahasa Arab pada berbagai tingkatan dengan cara yang -sadar atau tidak- dipengaruhi oleh sistem linguistik Bahasa Madura.

\section{Metode Penelitian}

Rancangan dalam penelitian ini digunakan desain kualitatif dengan pendekatan kasus. Kasus dalam penelitian adalah interferensi sintaksis Bahasa Ibu (Madura) terhadap Bahasa Arab khususnya dalam keterampilan berbicara. Subjek dalam penelitian ini adalah mahasiswa Program Studi Pendidikan Bahasa Arab Sekolah Tinggi Agama Islam (STAI) Syaichona Moh. Cholil Bangkalan. Jumlah keseluruhan mahasiswa adalah 150, peneliti hanya mengambil sampel sejumlah 40 mahasiswa, yang terdiri dari 3 kelas menurut data Lembaga Pengembangan Bahasa Asing di STAI Syaichona Moh. Cholil Bangkalan (mubtadi', mutawassit dan mutaqaddim). Mahasiswa dari kelas mubtadi' dan mutawassit sebanyak 25 orang, mereka membuat melakukan muhadatsah di depan kelas, berbincang di kafe dan musholla. Sedangkan mahasiswa dari kelas mutaqaddim sebanyak 15 orang menjawab pertanyaan-pertanyaan yang berbentuk argumentatif, karena kelas mutaqaddim ini merupakan kelas bahasa Arab unggulan di STAI Syaichona Moh. Cholil Bangkalan. 
Metode pengumpulan data yang digunakan dalam penelitian ini adalah: interview, observasi dan dokumentasi. Pengambilan data dalam penelitian ini adalah dari hasil pembelajaran Bahasa Arab materi Muhadasah mahasiswa PBA STAI Syaichona Moh. Cholil Bangkalan. Untuk data wawancara dilakukan dengan dosen pengampu mata kuliah Muhadatsah (Keterampilan Berbicara) yaitu Bapak H. Mujib Ahmad, Lc, MA dan pengurus Lembaga Pengembangan Bahasa Asing STAI Syaichona Moh. Cholil Bangkalan yaitu Ibu Dra. Aminah, M.Pd.I serta beberapa sampel mahasiswa Pendidikan Bahasa Arab STAI Syaichona Moh. Cholil Bangkalan. Sedangkan untuk observasi dilakukan oleh penulis sendiri yang bertindak sebagai observer dan melakukan eksperimen. Data dianalisis menggunakan analisis kualitatif dengan mengidentifikasi kesalahan-kesalahan berbahasa, menganalisis, dan menginterpretasi temuan penelitian berdasarkan tujuan penelitian yang ditetapkan.

\section{Hasil Penelitian dan Pembahasan}

Dari hasil observasi diperoleh data kalimat-kalimat yang termasuk kategori interferensi Bahasa Ibu (Madura) terhadap Bahasa Arab:

\begin{tabular}{|c|c|c|c|}
\hline No & Ungkapan & Seharusnya & $\begin{array}{l}\text { Dalam Bahasa } \\
\text { Indonesia/Madura }\end{array}$ \\
\hline 1 & مهلا-مهلا & مهلا & Pelan-pelan/On-Laon \\
\hline 2 & أنا ما عندي وقت & ليست لديّ فرصة & $\begin{array}{l}\text { Saya tidak punya } \\
\text { kesempatan } / \text { lo' andik } \\
\text { bektoh }\end{array}$ \\
\hline 3 & من أين أنت تناول هذا & أنّى للك هذا & $\begin{array}{l}\text { Dari mana kamu dapatkan } \\
\text { ini? Dheri dhimmah areyyah }\end{array}$ \\
\hline 4 & أنا أمزح فقط & لاَ أقصد منه الاّ المزاح & $\begin{array}{l}\text { Saya hanya bercanda/keng } \\
\text { aghajhe' }\end{array}$ \\
\hline 5 & ما في انسان في الفصل & ما بالفصل من أحد & $\begin{array}{l}\text { Tidak ada seorangpun di } \\
\text { kelas/tadhe' oreng e kellas }\end{array}$ \\
\hline 6 & لا أفهم ماذا تريد & لم أفهم بوضوح ما تريد & $\begin{array}{l}\text { Saya tidak paham apa } \\
\text { maumu/engko' lo' paham } \\
\text { pangeterrona be'eng }\end{array}$ \\
\hline
\end{tabular}




\begin{tabular}{|c|c|c|c|}
\hline 7 & هيّا بنا نعمل معا معا & هيّا بنا نعمل بدا بيد & $\begin{array}{l}\text { Ayo kita kerja } \\
\text { sama/majuh alakoh bhereng }\end{array}$ \\
\hline 8 & خذي ني الماء في & خذي لي كوبا من الماء & Ambilkan saya segelas air \\
\hline 9 & الذي ينجح؟ هو بنفسه & غو حده ينجح؟ & $\begin{array}{l}\text { Benarkah dia satu-satunya } \\
\text { anak yang berhasil }\end{array}$ \\
\hline 10 & نَحْنُ وَاجِبِ نَسْتَمِعُ & وَجَبَ عَلَيْنَا أنْ نَسْتَمِعَ & Kita harus mendengarkan \\
\hline 11 & أحسن أنت تبدأ الآن & 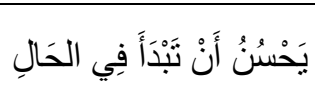 & $\begin{array}{l}\text { Sebaiknya kamu mulai } \\
\text { dari sekarang }\end{array}$ \\
\hline 12 & 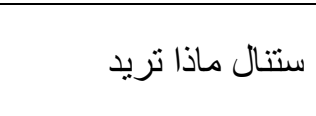 & لَبُّهُ & $\begin{array}{l}\text { Dia akan mendapatkan } \\
\text { apa yang dicari }\end{array}$ \\
\hline 13 & الوقت لم يز لا صباح & الَ الوَقَتُتُ مُبَكِرًا & $\begin{array}{l}\text { Waktunya masih pagi- } \\
\text { pagi sekali }\end{array}$ \\
\hline 14 & سَفَرَخَتُ أَسْكُنُ هُنَا & & $\begin{array}{l}\text { Saya pasti akan senang } \\
\text { sekali disini }\end{array}$ \\
\hline 15 & 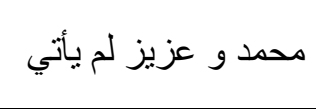 & مَا أَنَى مُحَمَّدُ وَلاَ عَزيْزٌْ & $\begin{array}{l}\text { Muhammad dan Aziz } \\
\text { tidak datang }\end{array}$ \\
\hline 16 & ما رأيتها في البيت باتة & مَا رَأَيْنْهَا قَطُُّ فِي البَيَتِ & $\begin{array}{l}\text { Saya tidak melihatnya } \\
\text { sama sekali di rumah }\end{array}$ \\
\hline 17 & غدا نحن مشغول جدا & سَنَكُوْنْ مُشْتْنَفِلْيْنَ غَدًا & Kita akan sibuk besok \\
\hline 18 & جدأب جدا... هذا جميل & أَعْجِبْْ بِمِنْلِ هَذَا الجَمَالِ & $\begin{array}{l}\text { Saya sangat kagum } \\
\text { dengan keindahan ini }\end{array}$ \\
\hline 19 & فصل هناك خلاص & ذللك الفصل قد انتهى & $\begin{array}{l}\text { Pembelajaran di pasal ini } \\
\text { sudah selesai }\end{array}$ \\
\hline 20 & أنظرْ فقط & 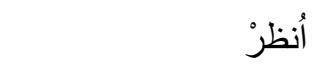 & Lihat saja \\
\hline 21 & ينام دائما في الفصل & ينام في الفصل دائما & Dia suka tidur di kelas \\
\hline 22 & أستعير قلم & أستعير قلمك & Saya pinjam bolpenmu \\
\hline 23 & الأستاذ تحضر؟ & هل الأستاذ يـحضر؟ & $\begin{array}{l}\text { Apakah ustad akan } \\
\text { datang? }\end{array}$ \\
\hline
\end{tabular}




\begin{tabular}{|c|c|c|c|}
\hline 24 & خلاص, اكتب فقط! & اكتب! & Sudahlah, tulis saja! \\
\hline 25 & 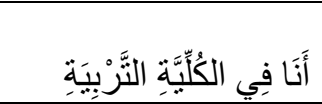 & أَنَا فِي كُلِيَّةِة النَّرْبِيَة & $\begin{array}{l}\text { Saya belajar di Fakultas } \\
\text { Tarbiyah }\end{array}$ \\
\hline 26 & كيف ناتجتك؟ & كيف بنتيجتلك؟ & $\begin{array}{l}\text { Bagaimana nilai (ujian) } \\
\text { mu? }\end{array}$ \\
\hline 27 & أنت خلاص اكل ؟ & أكلت & $\begin{array}{l}\text { Apakah kamu sudah } \\
\text { makan? }\end{array}$ \\
\hline 28 & 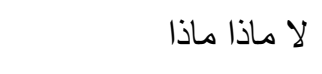 & لابأس بـ , لا مانع & Tidak apa-apa \\
\hline 29 & أنا مسرور بلقائك & أنا مسرورة بلقائلك & $\begin{array}{l}\text { Saya sangat senang } \\
\text { berjumpa denganmu }\end{array}$ \\
\hline 30 & أَنَا اُطُلْبُ فُلُسُلكَ & لو سمحت أطلب منلك & Saya minta uangmu \\
\hline 31 & 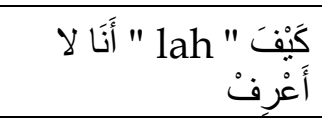 & لم أعرف بعد & $\begin{array}{l}\text { Bagaimana ini...saya } \\
\text { masih belum tahu }\end{array}$ \\
\hline 32 & أَنَتْ خَلاص دَفَع & دفعت المصروفات & Saya sudah membayar \\
\hline 33 & 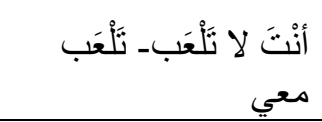 & ي يا أخي & $\begin{array}{l}\text { Jangan main-main } \\
\text { denganku }\end{array}$ \\
\hline 34 & نَحْنُ نَذْهَب سو اء-سواء & نذهب سويا & $\begin{array}{l}\text { Ayo kita berangkat } \\
\text { bersama! }\end{array}$ \\
\hline 35 & لَذَبْْذ جِدَّا أنْتَتِ & كنت مرتاحة & Enak sekali kamu! \\
\hline 36 & مَا فِي كَمَنْ & لم يكن موجودا بعد & Tidak ada lagi \\
\hline 37 & مَاءُهُ كَثِيْرِ & الماء كثير جدا & Airnya banyak sekali \\
\hline 38 & أَنْتَتَ إإحمِلْ ماذَا & ماذا تحمل؟ ماذا بيدك؟ & Kamu membawa apa? \\
\hline 39 & أنْتَنَ مَوْجُود قَلَمْ ؟ & هَلْ عِنْدَكَك قَلَمَ ؟ & $\begin{array}{l}\text { Apakah kamu } \\
\text { mempunyai bolpen? }\end{array}$ \\
\hline 40 & يجوز أستعير مكنسة ؟ & أجازلي أن أستعبر & $\begin{array}{l}\text { Bolehkah saya pinjam } \\
\text { sapu? }\end{array}$ \\
\hline 41 & أَنْت تريد تأكل معا أنا؟ & هل تريدين أن تأكلي & $\begin{array}{l}\text { Apakah kamu mau makan } \\
\text { dengan saya }\end{array}$ \\
\hline
\end{tabular}




\begin{tabular}{|c|c|c|c|}
\hline 42 & أنا لا أعرف ماذا ماذ & ما عرفت شيئا & Saya tidak tahu apa-apa \\
\hline 43 & أنت مريضة ماذا؟ & المرض؟ ماذاني من & Kamu sakit apa? \\
\hline 44 & أنا لا أريد & لا أربد..آسف يا أخي & Saya tidak mau lah... \\
\hline 45 & خلاس من أنا & كَفَبْتُ مِنِّي & Cukup sekian dari saya \\
\hline 46 & إِستِْخْدَامُ الْوَقَتُتُ & تَنْظِنِيْمُ الْوَقَتُت & Manajemen waktu \\
\hline 47 & 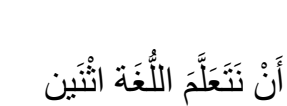 & أَنْ نَنَعَلَّمَ اللَُُْتَنَيْنِ & $\begin{array}{l}\text { Hendaklah kita belajar } \\
\text { dua bahasa }\end{array}$ \\
\hline 48 & وَجَجَ هَدَفْ كَثْيْرِ & 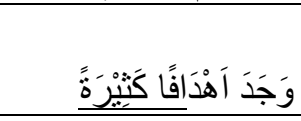 & $\begin{array}{l}\text { Dia mempunyai banyak } \\
\text { tujuan }\end{array}$ \\
\hline 49 & أَنَا فِي المستوَى ثُلاث & أَنَا فِي المستوَى الثنَّلِثَةِة & Saya di semester tiga \\
\hline
\end{tabular}

Dari hasil analisis ternyata banyak ditemukan kesalahan interferensi sintaksis, sebagai berikut.

Tabel 2

Daftar Kalimat Interferensi Bahasa Ibu Terhadap Bahasa Arab

\begin{tabular}{|c|c|c|c|c|}
\hline No & Ungkapan & Seharusnya & $\begin{array}{l}\text { Dalam Bahasa } \\
\text { Indonesia }\end{array}$ & Jenis Interferensi \\
\hline 1 & مهلا-مهلا & مهلا & Pelan-pelan & $\begin{array}{l}\text { Kesalahan } \\
\text { penggunaan kata }\end{array}$ \\
\hline 2 & وقا ما عندي & ليست لديّ & $\begin{array}{l}\text { Saya tidak punya } \\
\text { kesempatan }\end{array}$ & $\begin{array}{l}\text { Kesalahan bentuk } \\
\text { naïf }\end{array}$ \\
\hline 3 & تناول هذا أنت & أنّى للك هذا & $\begin{array}{l}\text { Dari mana kamu } \\
\text { dapatkan ini? }\end{array}$ & $\begin{array}{l}\text { Kesalahan bentuk } \\
\text { istifham }\end{array}$ \\
\hline 4 & أنا أمزح فقط & لاً أقصد منه الاً & $\begin{array}{l}\text { Saya hanya } \\
\text { bercanda }\end{array}$ & $\begin{array}{l}\text { Kesalahan bentuk } \\
\text { idiom }\end{array}$ \\
\hline 5 & ما فيلّ انسان في & ما مالفصل من & $\begin{array}{l}\text { Tidak ada } \\
\text { seorangpun di } \\
\text { kelas }\end{array}$ & $\begin{array}{l}\text { Kesalahan bentuk } \\
\text { idiom huruf Jar }\end{array}$ \\
\hline
\end{tabular}




\begin{tabular}{|c|c|c|c|c|}
\hline 6 & تريد أفهم ماذا & لم أفهم بوضوح & $\begin{array}{l}\text { Saya tidak paham } \\
\text { apa maumu }\end{array}$ & $\begin{array}{l}\text { Kesalahan bentuk } \\
\text { maf'ul bih dan } \\
\text { penempatan huruf } \\
\text { istifham }\end{array}$ \\
\hline 7 & هعيّا بنا نعمل معا & بيّيّا بنا نعمل يدا & $\begin{array}{l}\text { Ayo kita kerja } \\
\text { sama }\end{array}$ & $\begin{array}{l}\text { Kesalahan } \\
\text { penggunaan kosa } \\
\text { kata (semantik) }\end{array}$ \\
\hline 8 & في ألكوبي الماء & خن المي لي كوبا & $\begin{array}{l}\text { Ambilkan saya } \\
\text { segelas air }\end{array}$ & $\begin{array}{l}\text { Kesalahan } \\
\text { bentuktamyiz }\end{array}$ \\
\hline 9 & بنفسه صليح هو & أحقا هو حده & $\begin{array}{l}\text { Benarkah dia } \\
\text { satu-satunya } \\
\text { anak yang } \\
\text { berhasil }\end{array}$ & $\begin{array}{l}\text { Kesalahan } \\
\text { penggunaan kata }\end{array}$ \\
\hline 10 & 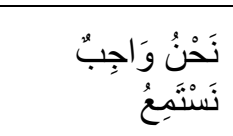 & نَسْنَجَعَ & $\begin{array}{l}\text { Kita harus } \\
\text { mendengarkan }\end{array}$ & $\begin{array}{l}\text { Kesalahan bentuk } \\
\text { fi'il māḍi }\end{array}$ \\
\hline 11 & الآن & 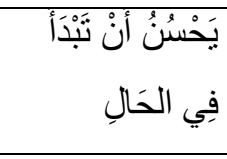 & $\begin{array}{l}\text { Sebaiknya kamu } \\
\text { mulai dari } \\
\text { sekarang }\end{array}$ & $\begin{array}{l}\text { Kesalahan bentuk } \\
\text { fiil }\end{array}$ \\
\hline 12 & ستنال ماذا تريد & 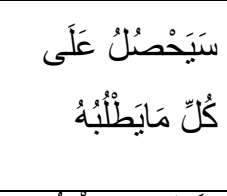 & $\begin{array}{l}\text { Dia akan } \\
\text { mendapatkan apa } \\
\text { yang dicari }\end{array}$ & $\begin{array}{l}\text { Kesalahan bentuk } \\
\text { maf'ul bih dan } \\
\text { penempatan huruf } \\
\text { istifham }\end{array}$ \\
\hline 13 & صباح لم يز لا & 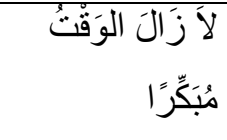 & $\begin{array}{l}\text { Waktunya masih } \\
\text { pagi-pagi sekali }\end{array}$ & $\begin{array}{l}\text { Kesalahan bentuk } \\
\text { jumlah fi'liyah }\end{array}$ \\
\hline 14 & هَنَفَرَخَتُ أَسُْْكُنُ & سَأفْرَحُح & $\begin{array}{l}\text { Saya pasti akan } \\
\text { senang sekali } \\
\text { disini } \\
\end{array}$ & $\begin{array}{l}\text { Kesalah bentukan } \\
\text { fi'il muḍāri }\end{array}$ \\
\hline 15 & لم يأتي و عزيز & 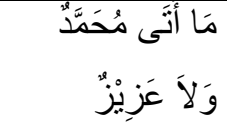 & $\begin{array}{l}\text { Muhammad dan } \\
\text { Aziz tidak datang }\end{array}$ & $\begin{array}{l}\text { Kesalahanbentuk } \\
\text { 'athaf dan dhamir }\end{array}$ \\
\hline 16 & مار أيتها في & 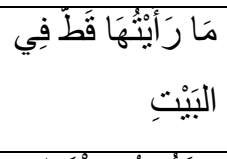 & $\begin{array}{l}\text { Saya tidak } \\
\text { melihatnya sama } \\
\text { sekali di rumah }\end{array}$ & $\begin{array}{l}\text { Kesalahan } \\
\text { penggunaan kosa } \\
\text { kat }\end{array}$ \\
\hline 17 & غشدا نحن & 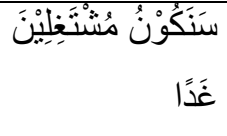 & $\begin{array}{l}\text { Kita akan sibuk } \\
\text { besok }\end{array}$ & $\begin{array}{l}\text { Kesalahan bentuk } \\
\text { hâl }\end{array}$ \\
\hline
\end{tabular}




\begin{tabular}{|c|c|c|c|c|}
\hline 18 & أتعجب جدا. . هذا & 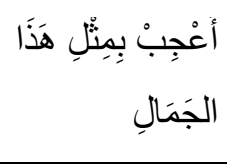 & $\begin{array}{l}\text { Saya sangat } \\
\text { kagum dengan } \\
\text { keindahan ini }\end{array}$ & $\begin{array}{l}\text { Kesalahan bentuk } \\
\text { isim ta'ajjub }\end{array}$ \\
\hline 19 & خلاصل هناك & ذلك الفصل قد & $\begin{array}{l}\text { Pembelajarandi } \\
\text { pasal ini sudah } \\
\text { selesai }\end{array}$ & $\begin{array}{l}\text { Kesalahanpenggun } \\
\text { aan kosa kata }\end{array}$ \\
\hline 20 & أنظرْ فقط & أنظرْ & Lihat saja & $\begin{array}{l}\text { Kesalahan } \\
\text { bentukfi'il }\end{array}$ \\
\hline 21 & الفصنل دائما في & بنام في الفصل & $\begin{array}{l}\text { Dia suka tidur di } \\
\text { kelas }\end{array}$ & $\begin{array}{l}\text { Kesalahan } \\
\text { penggunaan kosa } \\
\text { kata }\end{array}$ \\
\hline 22 & أستعير قلم & أستعير قلمك & $\begin{array}{l}\text { Saya pinjam } \\
\text { bolpenmu }\end{array}$ & $\begin{array}{l}\text { Kesalahan bentuk } \\
\text { maf'ul bih }\end{array}$ \\
\hline 23 & الأستاذ تحضر؟ & هل الأستاذ & $\begin{array}{l}\text { Apakah ustad } \\
\text { akan datang? }\end{array}$ & $\begin{array}{l}\text { Kesalahan bentuk } \\
\text { dhamir dan } \\
\text { penggunaan huruf } \\
\text { istifham }\end{array}$ \\
\hline 24 & فقاص! اكتب & اكتب! & $\begin{array}{l}\text { Sudahlah, tulis } \\
\text { saja }\end{array}$ & $\begin{array}{l}\text { Kesalahan bentuk } \\
\text { fiil amr }\end{array}$ \\
\hline 25 & 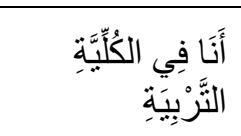 & 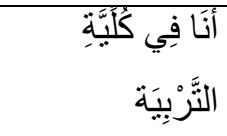 & $\begin{array}{l}\text { Saya belajar di } \\
\text { fakultas Tarbiyah }\end{array}$ & $\begin{array}{l}\text { Kesalahan bentuk } \\
\text { iḍāfah }\end{array}$ \\
\hline 26 & كيف ناتجتاك؟ & كيف بنتيجتاك؟ & $\begin{array}{l}\text { Bagaimana nilai } \\
\text { (ujian) mu? }\end{array}$ & $\begin{array}{l}\text { Kesalahan } \\
\text { penggunaan idiom }\end{array}$ \\
\hline 27 & أنت خلاص اكل & أكلت؟ & $\begin{array}{l}\text { Apakah kamu } \\
\text { sudah makan? }\end{array}$ & $\begin{array}{l}\text { Kesalahan bentuk } \\
\text { fi'il }\end{array}$ \\
\hline 28 & لا ماذا ماذا & لأبأس به , لانع & Tidak apa-apa & $\begin{array}{l}\text { Kesalahan } \\
\text { penggunaan istilah } \\
\text { / kosa kata }\end{array}$ \\
\hline 29 & بلقائك مسرور & بلقائلك مسرورة & $\begin{array}{l}\text { Saya sangat } \\
\text { senang berjumpa } \\
\text { denganmu }\end{array}$ & $\begin{array}{l}\text { Kesalahan bentuk } \\
\text { dhamir }\end{array}$ \\
\hline 30 & 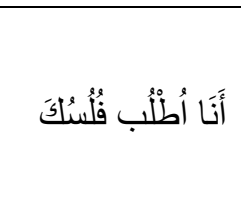 & أطلب منك ألكت & $\begin{array}{l}\text { Saya minta } \\
\text { uangmu }\end{array}$ & $\begin{array}{l}\text { Kesalahan bentuk } \\
\text { idiom }\end{array}$ \\
\hline
\end{tabular}




\begin{tabular}{|c|c|c|c|c|}
\hline 31 & 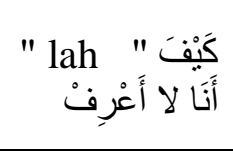 & لم أعرف بعد & $\begin{array}{l}\text { Bagaimana } \\
\text { ini..saya masih } \\
\text { belum tau }\end{array}$ & $\begin{array}{l}\text { Kesalahan kalimat } \\
\text { istifham }\end{array}$ \\
\hline 32 & أَنَتَتَ خَلاص دَفَع & المصتر & $\begin{array}{l}\text { Saya sudah } \\
\text { membayar }\end{array}$ & $\begin{array}{l}\text { Kesalahan bentuk } \\
\text { fi'il }\end{array}$ \\
\hline 33 & تَلَعَبَ معِي & ألا تلاعبني يا & $\begin{array}{l}\text { Jangan main- } \\
\text { main denganku }\end{array}$ & $\begin{array}{l}\text { Kesalahan bentuk } \\
\text { morfologis }\end{array}$ \\
\hline 34 & سَحْنُ نَذْهَب & سويا بنا نذهب & $\begin{array}{l}\text { Ayo kita } \\
\text { berangkat } \\
\text { bersama }\end{array}$ & $\begin{array}{l}\text { Kesalahan bentuk } \\
\text { hâl }\end{array}$ \\
\hline 35 & لََذَيْنْ جِدَّا أنْتَتَ & كنت مرتاحة & $\begin{array}{l}\text { Enak sekali } \\
\text { kamu! }\end{array}$ & $\begin{array}{l}\text { Kesalahan } \\
\text { penggunaan kosa } \\
\text { kata }\end{array}$ \\
\hline 36 & مَا فِي كَمَنْ & بعد بكن موجودا & Tidak ada lagi & $\begin{array}{l}\text { Kesalahan bentuk } \\
\text { jazm }\end{array}$ \\
\hline 37 & مَاعهُ كَتْيْر & الماء كثير جدا & $\begin{array}{l}\text { Airnya banyak } \\
\text { sekali }\end{array}$ & $\begin{array}{l}\text { Kesalahan bentuk } \\
\text { dhamir }\end{array}$ \\
\hline 38 & أَنْتَ الإحمِلْ ماذَا & ماذا تحمل؟ ماذا & $\begin{array}{l}\text { Kamu membawa } \\
\text { apa? }\end{array}$ & $\begin{array}{l}\text { Kesalahan bentuk } \\
\text { fiil }\end{array}$ \\
\hline 39 & أَنْتَ مَوْجُود قَلَم & هَلْ عِنْدَكَك قَلَمَ ؟ & $\begin{array}{l}\text { Apakah kamu } \\
\text { mempunyai } \\
\text { bolpen? }\end{array}$ & $\begin{array}{l}\text { Kesalahan bentuk } \\
\text { dzorof }\end{array}$ \\
\hline 40 & مكنسة ؟ أستعير & أستعير مكنسة ؟ أن & $\begin{array}{l}\text { Bolehkah saya } \\
\text { pinjam sapu? }\end{array}$ & $\begin{array}{l}\text { Kesalahan bentuk } \\
\text { fi'il }\end{array}$ \\
\hline 41 & أَنْت تريد تأكل & تأكلي معي؟ تريدين أن & $\begin{array}{l}\text { Apakah kamu } \\
\text { mau makan } \\
\text { dengan saya }\end{array}$ & $\begin{array}{l}\text { Kesalahan bentuk } \\
\text { kalimat istifham, } \\
\text { dhamir dan hal }\end{array}$ \\
\hline 42 & أنا لا أعرف & ما عرفت شيئا & $\begin{array}{l}\text { Saya tidak tahu } \\
\text { apa-apa }\end{array}$ & $\begin{array}{l}\text { Kesalahan bentuk } \\
\text { maf'ul bih }\end{array}$ \\
\hline 43 & ماذا؟ مريضة & ماذا تعاني من & Kamu sakit apa? & $\begin{array}{l}\text { Kesalahan bentuk } \\
\text { kalimat istifham }\end{array}$ \\
\hline
\end{tabular}




\begin{tabular}{|c|c|c|c|c|}
\hline 44 & أنا لا أريد lah & لأخي أربد..آسف يا & $\begin{array}{l}\text { Saya tidak mau } \\
\text { ah }\end{array}$ & $\begin{array}{l}\text { Kesalahan bentuk } \\
\text { ungkapan }\end{array}$ \\
\hline 45 & خلاس من أنا & كَفَيْتُ مِنِّي & $\begin{array}{l}\text { Cukup sekian } \\
\text { dari saya }\end{array}$ & $\begin{array}{l}\text { Kesalahan bentuk } \\
\text { ungkapan }\end{array}$ \\
\hline 46 & إِسنْتِخْدَامُ الْوَقَتُتُ & تَنْظِطْيْمُ الْوَقَتَ & $\begin{array}{l}\text { Manajemen } \\
\text { waktu }\end{array}$ & $\begin{array}{l}\text { Kesalahan } \\
\text { penggunaan kata }\end{array}$ \\
\hline 47 & 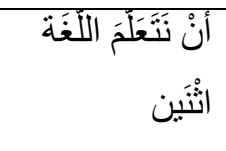 & أَنْنْ نَنَعَلَّمَ اللُلَْغَتَنْنِ & $\begin{array}{l}\text { Hendaklah kita } \\
\text { belajar dua } \\
\text { bahasa }\end{array}$ & $\begin{array}{l}\text { Kesalahbentukan } \\
\text { muṡanna }\end{array}$ \\
\hline 48 & وَجَدَ هَذَفْ كَثْيْرِ & 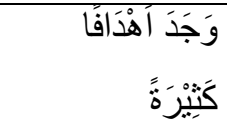 & $\begin{array}{l}\text { Dia mempunyai } \\
\text { banyak tujuan }\end{array}$ & $\begin{array}{l}\text { Kesalahan bentuk } \\
\text { jama' }\end{array}$ \\
\hline 49 & ثَأَنَا فِي المستوَى & 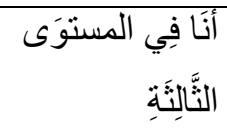 & $\begin{array}{l}\text { Saya di semester } \\
\text { tiga }\end{array}$ & $\begin{array}{l}\text { Kesalah bentukan } \\
\text { mużakkar }\end{array}$ \\
\hline
\end{tabular}

Interferensi sintaksis dapat terlihat pada penggunaan serpihan kata, frasa, dan klausa. Interferensi bahasa (sintaksis) pada penelitian ini terjadi pada problem bentuk kalimat dan problem kesesuaian susunan yang meliputi: bentuk tunggal, ganda, dan plural (ifräd, tasniyah dan jama'), jenis kelamin (mużakkar dan mu'annaś), problem i'räb, problem kalimat verbal (jumlah fi'iliyah), problem kalimat nominal (jumlah ismiyah), problem idiom Arab (kata yang disandingkan dengan huruf jar), problem penggunaan kosa kata yang tidak sesuai penempatan atau konteksnya, serta problem $n a^{\prime} a t$ dan iḍāfah.

Interferensi merupakan gejala penyusupan sistem suatu bahasa ke dalam bahasa lain. Interferensi bahasa -sintaksis- dalam hasil muhadasah mahasiswa STAI Syaichona Moh. Cholil Bangkalan di atas merupakan salah satu bentuk penyimpangan berbahasa. Karena unsur bahasa yang menyusup ke dalam struktur bahasa yang lain dapat menimbulkan dampak negatif. Gejala demikian terjadi karena ada beberapa faktor yang mempengaruhinya, baik dalam aspek linguistik maupun non linguistik. Secara aspek linguistik, terdapat dua faktor: 
1. Minimnya penguasaan kosa-kata (mufrodat).

Pernyataan ini berdasarkan dari hasil observasi dan wawancara peneliti pada 23 September 2017 dengan informan yang bernama Ririn Azriana, Naili, Ainul Fitria, Dina Kamalia Dewi, Dewi Farohah, Iklimah, Muthmainnah, Dawiyah, Roihatul Jannah, Fatimatus Zahra. Mufrodat menjadi kendala utama mahasiswa ketika berbahasa Arab. Dari 20 informan yang diwawancarai, terdapat 10 orang (50\%) mengeluhkan kurangnya mufrodat yang mereka kuasai. Tidak hafal banyak mufrodat menjadi kendala terbesar sehingga menyebabkan minimnya minat mahasiswa berbahasa Arab. Dina Kamalia Dewi mengungkapkan keluh kesahnya ketika peneliti mewancarainya. Ia mengatakan bahwa mufrodat yang minim jadi masalah utama dalam berbahasa Arab. Ia tidak tahu harus berbicara apa ketika tidak tahu mufrodatnya. Sehingga ia sering kali menggabungkan atau mencampurkan Bahasa Arab dengan Bahasa Indonesia/Madura.

Terbukti bahwa ketidakmampuan mahasiswa berbicara Bahasa Arab yang sesuai dengan kaidah Bahasa Arab terlihat dari minimnya mufradāt yang dihafal dan jarangnya berbicara menggunakan mufradāt Bahasa Arab dengan benar. Hal ini disebabkan karena kurangnya self-motivation (motivasi diri) mahasiswa dalam memperkaya kosa-kata dan mempraktikkannya, baik dalam komunikasi antarteman dalam kehidupan sehari-hari, begitu juga saat diberikan latihan-latihan dalam pembelajaran Maharah Kalam di kelas, seperti: sesi tanya jawab antara dosen dan mahasiswa, diskusi kelas, dan sebagainya.

2. Minimnya pemahaman dan pengetahuan tentang kaidah Bahasa Arab secara aplikatif.

Nama-nama informan wawancara dari mahasiswa Pendidikan Bahasa Arab STAI Syaichona Moh. Cholil Bangkalan adalah: Nurul Ilmiah, Kutsiatul Muamalah, Puspita Sari, Khairun Nisak, Ika Hardiyani, Aniyatul Hikmah, Jamilah.

Kendala berikutnya yang menjadi penyebab mahasiswa enggan berbahasa Arab adalah pemahaman kaidah Bahasa Arab yang minim. Beberapa informan mengatakan mereka cukup banyak hafal mufrodat namun mereka kesulitan merangkai kalimat Bahasa Arab yang baik dan 
benar sesuai kaidah nahwu dan shorof. Ada sekitar 7 orang (35\%) dari 20 informan yang peneliti wawancara, menjadikan kaidah Bahasa Arab sebagai permasalahan utama mereka ketika harus berbahasa Arab. Nurul Ilmiah, salah satu mahasiswi STAIS Syaichona Moh. Cholil mengatakan, kurangnya pemahaman akan kaidah Bahasa Arab membuat dirinya kesulitan ketika berbicara Bahasa Arab. Ia tidak tahu bagaimana mengucapkan Bahasa Arab yang baik dan benar sesuai kaidah yang berlaku walaupun ia hafal begitu banyak kosa kata. Hal ini menjadi perhatian peneliti bahwa banyak kosa kata yang diketahui tidak menjadikan seseorang lancar berbahasa Arab, ada faktor lain yang membuat mahasiswa/mahasiswi sulit berbicara Bahasa Arab yaitu faktor kaidah bahasa Arab.

Beberapa mahasiswa juga sering mengaku kebingungan dan sering salah dalam menggunakan kaidah atau tata bahasa tersebut secara bersamaan, hal itulah yang menjadi penyebab utama interferensi sintaksis terjadi. Selain itu interferensi juga terjadi karena kurangnya pengetahuan mahasiswa dalam memilih diksi yang sesuai dan mayoritas dari mereka langsung mengungkapkannya sebagaimana yang ada di kamus, tanpa memperhatikan asal kata tersebut. Sintaksis dalam Bahasa Arab juga disebut dengan ilmu nahwu. Jamak diketahui, dalam pembelajaran ilmu nahwu kaidah tidak hanya cukup dihafal akan tetapi juga harus fungsional, dalam arti pembelajaran kaidah juga harus dipaparkan dalam banyak contoh sehingga mudah diaplikasikan seharihari oleh mahasiswa ke dalam struktur Bahasa Arab dengan baik dan benar.

Adapun faktor penyebab munculnya interferensi sintaksis Bahasa Ibu terhadap Bahasa Arab dari aspek non linguistik ialah:

1. Faktor demotivasi (kurangnya motivasi) mahasiswa dalam berkomunikasi Bahasa Arab sehari-hari.

Pernyataan tersebut berdasarkan hasil observasi dan wawancara oleh Nurul Ilmiyah, salah satu mahasiswa STAI Syaichona Moh. Cholil Bangkalan pada tanggal 3 Oktober 2017. Ia menyatakan bahwa kebanyakan mahasiswa STAI Syaichona Moh. Cholil Bangkalan malas berkomunikasi dengan menggunakan Bahasa Arab, mereka lebih sering 
menggunakan Bahasa Indonesia dan bahasa daerah dalam kegiatan sehari-hari karena dianggap lebih praktis dan dimengerti. Mereka berbahasa Arab hanya karena takut ketika ada pengurus di lembaga pendidikan bahasa asing karena akan dikenai sanksi yang cukup berat apabila tidak berbahasa Arab, selain itu juga mereka berbahasa Arab hanya di mata kuliah yang memang menuntut mereka melakukan latihan berbahasa intensif, seperti Muhadasah, Istima' dan lain sebagainya.

2. Faktor tekanan psikologis (rasa malu)

Dua mahasiswi STAIS Syaichona Moh. Cholil, Faza dan Sa'adah enggan berbahasa Arab dikarenakan tidak percaya diri dan malu untuk mengungkapkan kalimat Bahasa Arab. Ketika peneliti mengajak mereka berdua berbicara dengan Bahasa Arab, mereka paham dengan apa yang peneliti katakan, tapi mereka malu dan tidak percaya diri berbicara Bahasa Arab. Ada $10 \%$ dari 20 Mahasiswa yang peneliti wawancarai, tidak percaya diri dan malu berbicara dengan Bahasa Arab.

Rasa malu ini muncul karena kemampuan berbahasa yang belum memadai. Seperti adanya perasaan takut salah, baik karena takut salah pada mufradat yang dipakai, kaidah yang digunakan, dan kurang terlatih berbicara karena lingkungan yang belum banyak membentuk untuk berbahasa Arab sehari-hari.

3. Faktor kurangnya pembiasaan (habitat berbahasa Arab)

Beberapa informan saat wawancara mengeluhkan kurangnya pembiasaan mereka dengan berbahasa Arab dalam kehidupan seharihari. Pada hakikatnya, belajar berbahasa adalah ilmu terapan, yang mengharuskan pembelajarnya menerapkan ilmu tersebut secara kontinyu tanpa henti. Baik dengan cara mempraktikkannya sehari-hari maupun mengerjakan latihan-latihan komunikasi dan kepenulisan yang intens, sehingga ilmu tersebut selalu diasah dan berkembang. Oleh karena itulah lingkungan berbahasa mutlak dibutuhkan oleh para pembelajar bahasa asing, tak terkecuali pembelajar Bahasa Arab di STAI Syaichona Moh. Cholil Bangkalan ini.

Dengan adanya lingkungan berbahasa maka pembiasaan berbahasa juga akan terbentuk. Terbawanya kebiasaan dalam bahasa pertama (Bahasa 
Madura) pada bahasa penerima yang sedang digunakan pada umumnya terjadi karena kurangnya kontrol bahasa dan kurangnya penguasaan terhadap bahasa penerima. Hal ini dapat terjadi pada seseorang sedang belajar bahasa kedua, baik bahasa nasional maupun bahasa asing. Dalam penggunaan bahasa kedua, pemakai bahasa kadang-kadang kurang kontrol dan kesulitan karena minimnya pembiasaan dan habitat yang melatihnya.

4. Faktor kebutuhan akan perpadanan bahasa pertama terhadap bahasa kedua.

Hal ini berdasarkan observasi pada tanggal 06 Oktober 2017. Peneliti mengamati sejumlah mahasiswa yang sering melakukan interferensi dalam bentuk penyerapan atau peminjaman kosa kata baru dari bahasa sumber untuk memberikan sinonim/perpadanan kata pada bahasa kedua yaitu dalam Bahasa Arab, kemudian mengalih-bahasakan ke dalam bahasa pertama (Bahasa Ibu). Peneliti juga melakukan wawancara dengan Fatimatuz Zahra' salah satu mahasiswa semester tiga Pendidikan Bahasa Arab STAI Syaichona Moh. Cholil Bangkalan. Ia menyatakan: "Seringkali saya menghadapi kesulitan menemukan kosakata dalam Bahasa Arab, yang saya pikir sangat berbeda sekali dengan Bahasa Indonesia, maka untuk lebih praktisnya, saya bumbuhin (tambahkan) dengan campuran istilah dalam Bahasa Indonesia aja". Dari pernyataan tersebut dapat disimpulkan bahwa mahasiswa masih meminjam kosa kata bahasa pertama jika mereka tidak menemukan dalam Bahasa Arab, dan mereka enggan mencari tahu tentang kesulitan-kesulitan yang mereka hadapi.

5. Faktor perbedaan yang signifikan antara bahasa Arab dan bahasa Indonesia.

Perbedaan bahasa pertama (Bahasa Madura/Indonesia) dan bahasa kedua (Bahasa Arab) terdapat dalam beberapa hal yang meliputi hal pluralitas kata, gender dalam kata, i'rāb, șaraf, dan penggunaan idiom dengan huruf jar (ta'alluq). Ada juga pendapat tentang sumber kekacauan berbahasa lain. Menurut Brown sumber kesilapan bahasa ada tiga, dan interferensi termasuk salah satu kekacauan berbahasa, 
yaitu kesalahan interlingual transfer, intralingual transfer, dan kekacauan karena konteks pembelajaran (context of learning) 4

Testimoni faktor-faktor penyebab terjadinya interferensi bahasa (sintaksis) dalam hasil muhadatsah mahasiswa STAI Syaichona Moh.Cholil Bangkalan tersebut cenderung membuat prihatin oleh kalangan dosen dan pemerhati Bahasa Arab. Maka dari itu, diperlukan beberapa solusi alternatif guna meminimalisasi terjadinya permasalahan-permasalahan di atas. Langkah yang peneliti lakukan pada tahap ini adalah dengan melakukan wawancara dengan dosen pengampu mata kuliah Muhadatsah STAI Syaichona Moh. Cholil Bangkalan pada 20 Oktober 2017.

Berdasarkan hasil wawancara dengan dosen pengampu mata kuliah tersebut yang bernama H. Mujib Ahmad, Lc, MA dapat disimpulkan bahwa hal yang sedikit menghambat proses pembelajaran adalah tingkat kemampuan mahasiswa yang berbeda-beda. Latar belakang pendidikan mahasiswa yang tidak sama antara satu dengan yang lain. Ada yang berlatar pendidikan pesantren, ada pula yang berlatar pendidikan umum. Maka hal ini menjadi point kesulitan dosen pengajar dalam menyampaikan materi ajar. Sehingga proses pembelajaran harus dimulai dari awal. Metode yang digunakan harus bervariasi agar mahasiswa tetap antusias terhadap Bahasa Arab.

Selain itu, peneliti juga mendatangkan Native Speaker (penutur Arab) berkebangsaan Arab meminta saran dari reviewer dari penutur Arab Asli ini. Beliau adalah Prof. Dr. Sulaiman Hasan Sulaiman asal Lybia yang merupakan Dosen Dirasat Islamiyah Pascasarjana Universitas Negeri Malang untuk memperbaiki kesalahan-kesalahan berbahasa mahasiswa Pendidikan Bahasa Arab STAI Syaichona Moh. Cholil Bangkalan yang sudah peneliti kumpulkan kalimat-kalimat tergolong interferensi tersebut untuk kemudian diperbaiki ke dalam uslub (gaya bahasa) Arab yang benar dan fasih. Selain itu, peneliti juga mengundang reviewer yang merupakan dosen pakar Bahasa Arab yang didatangkan dari Institut Dirosat Islamiyah Al-Amien (IDIA) Sumenep Madura pada 26 Oktober dan 5 November 2017, yaitu Ustad Saiful Anam, Lc, M.Pd.I dan peneliti meminta

${ }^{4}$ Moh. Ainin, 2011: 61-63 
keterangan dari kedua dosen tersebut agar memberikan solusi-solusi konstruktif guna meminimalisir terjadinya interferensi bahasa berikutnya, terutama dalam interferensi sintaksis pembelajaran muhadatsah di STAI Syaichona Moh. Cholil Bangkalan.

Beberapa solusi dari Prof. Dr. Sulaiman Hasan Sulaiman (Penutur Arab asli asal Lybia) dan Ustad Saiful Anam, Lc, M.Pd.I (Dosen Bahasa Arab IDIA Sumenep) adalah:

1. Pembentukan "Asrama Bahasa" sebagai upaya pembentukan habitat berbahasa asing, khususnya Bahasa Arab bagi mahasiswa. Lembaga Pengembangan Bahasa Asing (LPBA) seyogyanya merancang banyak program-program kebahasaan yang lebih intensif terhadap mahasiswa Program Studi Pendidikan Bahasa Arab, lebih dari itu, pengembangan bahasa asing ini juga sejalan dengan tujuan dari kurikulum Perguruan Tinggi yang diberlakukan oleh Kemenristek DIKTI RI yaitu SN-DIKTI KKNI (Standar Nasional-Pendidikan Tinggi Kerangka Kualifikasi Nasional Indonesia) yang menggalakkan penguasaan bahasa asing bagi mahasiwa Indonesia sehingga dapat terampil memiliki kecakapan bahasa asing baik tingkat nasional bahkan internasional.

2. Optimalisasi Markaz Lughah (Pusat Bahasa) dengan memarakkan kursus bahasa di luar jam kuliah. Lembaga Pengembangan Bahasa Asing memiliki peran sangat strategis dalam hal ini.

3. Pengembangan materi ajar. Selama ini belum ada panduan khusus untuk materi pembelajaran Muhadatsah di STAI Syaichona Moh. Cholil Bangkalan. Maka buku ajar yang dipenuhi latihan-latihan berbahasa ini cukup urgen bagi kebutuhan mahasiswa saat ini, senada dengan permasalahan kebahasaan mereka. Hendaknya dosen merencanakan pengajaran secara matang serta perlu dilakukan evaluasi baik dari segi materi maupun strategi pengajarannya. Dimulai dari buku ajar harus ada panduan yang jelas agar mahasiswa tidak kebingungan dan bisa belajar sendiri tanpa menunggu dosen, serta pengajaran nahwu mengikuti prinsip pembalajaran bahasa, yaitu: dimulai dari hal yang mudah ke yang lebih sulit, dari yang sudah diketahui sampai yang belum diketahui, dan materi yang diajarkan harus runtut dan berproses dalam artian materi yang akan diajarkan sekarang harus ada 
kaitannya dengan materi pelajaran pada bab sebelumnya, baik dari aspek kosakata, nahwu, maupun yang lainnya. Sehingga meminimalisasi kebingungan mahasiswa, dengan melihat kemampuan mahasiswa yang berbeda-beda tersebut.

4. Pengembangan metode pengajaran yang sesuai dengan pembelajaran, yaitu dengan cara mengevaluasi beberapa metode yang sudah pernah digunakan, kemudian dari hasil evaluasi tersebut dipilih metode yang paling sesuai dan "menjawab" kebutuhan mahasiswa dan "mujarab" mengatasi kesalahan-kesalahan kebahasaan mahasiswa.

5. Perlu dilakukan evaluasi dan pengembangan dalam metode pengajaran dosen, di antaranya adalah tanpa diawali dengan menerjemahkan dalam Bahasa Indonesia terlebih dahulu, akan tetapi langsung menerjemahkan secara lisan ke dalam Bahasa Arab. Karena hal tersebut bisa meminimalisir terjadinya interferensi. Pembelajaran Bahasa Arab juga disesuaikan dengan level yang dikuasai mahasiswa, karena tentunya setiap level memiliki target tersendiri mengenai pembelajaran Bahasa Arab. Di akhir proses pembelajaran dosen harus selalu mengevaluasi tingkat pemahaman mahasiswa terkait materi perkuliahan yang sudah diajarkan, bisa dengan cara melakukan tanya jawab ataupun yang lainnya, sehingga bisa dipastikan dan disimpulkan setelah selesai perkuliahan semua mahasiswa memahami penerapan teknik-teknik yang strategis dalam mengajar yang lebih dapat membantu mahasiswa dalam memperbaiki kesalahannya, khususnya terkait interferensi.

Kelima solusi demikian diharapkan mampu meminimalkan terjadinya interferensi bahasa di kalangan mahasiswa STAI Syaichona Moh. Cholil Bangkalan, terutama dalam pembelajaran Muhadatsah. Dengan tujuan akhir, mahasiswa pandai/fasih dalam berbahasa Arab, terutama pandai dalam berbicara (Mahārah al-Kalam) bisa terwujud sesuai dengan tujuan pendidikan Bahasa Arab yang telah ditetapkan sebelumnya.

\section{Simpulan}

Interferensi sintaksis dapat terlihat pada penggunaan serpihan kata, frasa, dan klausa. Interferensi bahasa (sintaksis) pada penelitian ini terjadi 
pada problem bentuk kalimat dan problem kesesuaian susunan yang meliputi: bentuk tunggal, ganda dan plural (ifräd, tasiniyah dan jama'), jenis kelamin (mużakkar dan mu'annaś), problem i'räb, problem kalimat verbal (jumlah fi'iliyah), problem kalimat nominal (jumlah ismiyah), problem idiom Arab (kata yang disandingkan dengan huruf jar), problem penggunaan kosa kata yang tidak sesuai penempatan atau konteksnya, serta problem $n a^{\prime} a t$ dan iḍäfah.

Faktor penyebab munculnya interferensi sintaksis Bahasa Ibu terhadap keterampilan berbicara mahasiswa Pendidikan Bahasa Arab STAI Syaichona Moh. Cholil Bangkalan terbagi ke dalam dua faktor, yaitu problematika linguistik dan non-linguistik. Aspek linguistik meliputi: minimnya penguasaan kosa-kata dan minimnya pemahaman dan pengetahuan tentang kaidah bahasa Arab secara aplikatif. Aspek non linguistik meliputi: faktor demotivasi (kurangnya motivasi) mahasiswa dalam berkomunikasi Bahasa Arab sehari-hari, tekanan psikologis (rasa malu), faktor kurangnya pembiasaan (habitat berbahasa Arab), kebutuhan akan perpadanan bahasa pertama terhadap bahasa kedua, dan faktor perbedaan yang signifikan antara Bahasa Arab dan Bahasa Indonesia.

Perlunya pelatihan penerapan kosa-kata secara intens, tidak hanya dengan menghafalkan kosa-kata tetapi mahasiswa juga harus banyak mendapatkan latihan-latihan mendengar, berbicara, membaca dan menulis dalam Bahasa Arab untuk mengasah keterampilan berbahasa mereka menjadi lebih baik. Pembelajaran sintaksis Bahasa Arab seyogyanya diarahkan untuk mengatasi masuknya sistem urutan Bahasa Indonesia dalam ujaran Bahasa Arab, karena maraknya penggunaan pola kerancuan Bahasa Indonesia dalam komunikasi Bahasa Arab mahasiswa Pendidikan Bahasa Arab STAI Syaichona Moh. Cholil Bangkalan. Dengan diarahkannya pengetahuan tentang masuknya unsur Bahasa Indonesia ke dalam bahasa Arab, sehingga nantinya mahasiswa akan lebih berkompeten dalam berkomunikasi menggunakan struktur Bahasa Arab dengan baik dan benar. 
Belajar bahasa pada hakikatnya adalah belajar komunikasi. Oleh karena itu pembelajaran Bahasa Arab hendaknya diarahkan untuk meningkatkan kemampuan pembelajar dalam berkomunikasi, baik lisan maupun tulis. Belajar bahasa juga long life process (proses yang berlangsung sepanjang hayat) yang harus dipraktikkan terus-menerus secara aktif dan aplikatif.

\section{DAFTAR PUSTAKA}

\section{Buku}

Ali, M. 1982. Penelitian Kependidikan. Bandung: Angkasa.

Al Wasilah, A. Chaedar. 1985. Beberapa Madhab dan Dikotomi Teori Linguistik, Bandung: Angkasa.

Bungin, Burhan. 2003. Analisis Data Kualitatif. Jakarta: Raja Grafindo.

Chaer, Abdul. 2009. Psikolinguistik Kajian Teoretik. Jakarta: Rineka Cipta, Cet II.

Chaer, Abdul. 2010. Sosiolinguistik Perkenalan Awal. Jakarta: Asdi Mahasatya.

Chaer, Abdul dan Leonie Agustina. 1995. Sosiolinguistik. Jakarta: Rineka Cipta.

Chaer, Abdul dan Leonie Agustina. 2004. Sosiolinguistik Perkenalan Awal, Jakarta: Rineka Cipta, Cet II.

Chomsky , Noam. Tt. Syntactic Structure, Cambrigde Mass: The MIT Press.

Dennes, M.I. 1994. Interferensi Bahasa Indonesia Dalam Pemakaian Bahasa Bali di Media Massa. Jakarta: Pusat Pembinaan dan Pengembangan Bahasa Departemen Pendidikan dan Kebudayaan. Lihat juga: 
"Jurnal Bahasa dan Seni Tahun 41 No.1, Februari. Fak. Keguruan dan Ilmu Pendidikan.Universitas Pasundan Bandung. 2013.

Huda, Nuril dkk. 1981. Interferensi Bahasa Madura Terhadap Bahasa Indonesia Tulis Murid Sekolah Dasar Jawa Timur. Jakarta : Pusat Pembinaan dan Pengembangan Bahasa.

Jendra, I Wayan. 1991. Dasar-dasar Sosiolinguistik. Denpasar: Ikayana.

Jassem Ali Jassem. 2000. Study On Second Language Learners Of Arabic: An Error Analysis Approach. Kuala Lumpur: Pustaka Hayathi.

Mardalis. 2008. Metode Penelitian Suatu Pendekatan Proposal. Jakarta: Bumi Aksara.

Margono. 2003. Metodologi Penelitian Pendidikan. Jakarta: Rineka Cipta.

Moleong, Lexy J. 2012. Metodologi Penelitian Kualitatif. Remaja Rosdakarya.

Poedjosoedarmo, Soepomo. 1989. Interferensi Gramatikal Bahasa Jawa dalam Pemakaian Bahasa Indonesia Murid SD. Laporan Penelitian, Yogyakarta: Depdikbud.

Rakhmawati, Yunita. 2011. Dasar-dasar Metodologi Penelitian PembelajaranBahasa Arab. Semarang: Sagha Grafika Solusindo.

Soewito. 1985. Pengantar Awal Sosiolinguistik: Teori dan Problema. Surakarta: Henary Cipta.

Sugiono. 2008. Metodologi Penelitian Kuantitatif Kualitatif dan $R \in \mathcal{E} D$. Bandung: Alfabeta.

Sukmadinata, Nana Syaodih. 2004. Metodologi Penelitian Pendidikan. Bandung: Remaja Rosdakarya.

Weinrich, Uriel. 1970. Language in Contact: Finding and Problems. Paris : The Hague.

Yatim, Riyanto. 2001. Metodologi Penelitian Pendidikan. Surabaya: SIC. 
Yusuf, Suhendra. 1994. Teori Terjemah Pengantar ke Arah Pendekatan Linguistik dan Sosiolinguistik. Bandung: Mandar Maju.

http : / / pusatbahasaalazhar.wordpress.com

\section{Tesis dan Jurnal}

Budiarty, Any. 2013. Interferensi Bahasa Indonesia Ke Dalam Bahasa Inggris Pada Abstrak Jurnal Ilmiah. Jurnal: Bahasa dan Seni, Vol. 41, No. 1, Februari 2013.

Pramudya, Mahar. 2006. Interferensi Gramatikal Bahasa Melayu Bangka dalam Pemakaian Bahasa Indonesia" : dengan Data Rubrik Makper dan Akek Buneng dalam Surat Kabar Bangka Pos. Skripsi, Program Studi Sastra Indonesia, Universitas Diponegoro. Tidak diterbitkan.

Sinambela. 2008. Interferensi Bahasa Indonesia Terhadap Bahasa Toba Pada Buku Khuṭbah Impola Ni Jamita. Tesis. Universitas Sumatera Utara. Tidak diterbitkan. 
Jurnal Pendidikan dan Pranata Islam 